\title{
GRAVITY INVERSION ON GRANITE-GREENSTONE BELT AREAS: CRIXÁS, GUARINOS AND PILAR DE GOIÁS, BRAZIL
}

\author{
MARCELO DE LAWRENCE BASSAY BLUM, AUGUSTO CESAR BITTENCOURT PIRES AND \\ ROBERTO ALEXANDRE VITORIA DE MORAES
}

\begin{abstract}
A gravity survey was carried out in the central and northern state of Goías portions, covering an area of $9000 \mathrm{~km}^{2}$ of granitegreenstone belt rock associations. Using a fixed density of $2.67 \mathrm{~g} / \mathrm{cm}^{3}$ and removing a second-degree trend surface for modeling and inversion, we determined the residual anomalies. Each anomaly was associated to well-known geological surface information, and airborne magnetic data and density determinations. Final solution was obtained in by interactive inversion. The initial models were generated in 2-D, for latter 2.5-D inversion, interpretation and geological sections sketching based on geologic knowledge. The anomalies were also inverted in 3-D in an automatic process. Estimated depths are coherent with those obtained in the 2.5 -D inversion, indicating the targets can reach $2 \mathrm{~km}$ deep.
\end{abstract}

Keywords:

INTRODUCTION Near to the surface, any lateral change of density produces local variations in the gravitational field value that, although very small, they can be detected, allowing evaluations regarding the distribution of the subsurface densities. To increase the density of a gravity station network in the Archean terranes of Central Brazil, and to continue the survey begun by Blum et al. (1996), a gravity survey was carried out over an area of $9000 \mathrm{~km}^{2}$ in the northern portion of these terranes (Fig. 1).

The aim of this paper is to model, by inversion, the gravity data to obtain the largest amount possible geological parameters. As solution ambiguity exists for that type of information, we used additional data, as aerial magnetic data of the Brazil-Canada's Geophysical Project (Carmo 1978), the well-known geology, densities obtained in laboratory, and susceptibilities of probe drill cores. Each anomaly was associated to a type of information, generally of surface character, leaving the final solution, or the most appropriate, to the inversion process.

REGIONAL GEOLOGY Three greenstone belts occur in the Crixás region (Crixás, Guarinos and Pilar de Goías) with ages around 2.9 Ga (Arndt et al. 1989), metamorphosed under greenschist facies and separated by granitoid complexes. The belts consist of lower tholeiite and basalt units and upper sedimentary units (lost and Oliveira 1991).

The area contains granitoid complexes of tonalitic - granodioritic composition and are known as Anta, Caiamar, Moquem and Hidrolina (lost etal. 1999).

GRAVITY DATA ORIGIN For the collection of the gravity data, a Lacoste \& Romberg gravimeter was used, with a precision is 0.01 mGal daily. The coordinates were obtained via a GPS 55 AVD of Garmin International, Inc., with approximate horizontal error of 100 $\mathrm{m}$. The altitudes in relation to the sea level were obtained with a Paulin altimeter accurate to the meter. Base - stations were defined starting from the Brazilian Fundamental Gravity Net (Escobar 1980), using the reference $\mathrm{RN}-1284-\mathrm{P}$ and $\mathrm{RN}-1283-\mathrm{C}$ located, respectively, in the cities of Itapaci and Crixás. The spacing between the stations varied from 1 to $2 \mathrm{~km}$ in profiles crossing greenstone belts. In any other geological situation, that spacing varied from 3 to $5 \mathrm{~km}$.

The data were collected on 396 different points. All the readings were corrected from the effect of the terrestrial tide due to the Sun and to the Moon, drift, and latitude, free-air, Bouguer corrections. The calculations of terrain corrections were done by a Hammer (1939) based method with digital terrain model (Blum 1999). Digital density evaluations were also made with a Parasnis (1972) based method (Blum 1999).

Carried out those procedures and added the stations previously collected (Marangoni 1994), the map of Bouguer anomalies is presented in the Fig. 2. In that illustration, each greenstone belt is easily observed with relationship to its gravity properties.

METHODOS The methods used in this paper involves the algorithms of Won and Bevis (1987), Webring (1985), and Cordell and Henderson(1968).
2-D Models and 2.5-D inversion Won and Bevis (1987) present two algorithms for the estimate of gravity and magnetic anomalies due to a polygon of $\mathrm{n}$ vertexes in a 2-D space. The algorithms were based on Talwani et al. (1959), Talwani (1965), and Grant and West (1965). The programs derived from those algorithms are interactive, allowing field generated by the proposed polygon be evaluated and compared with the curve of the observed field. The programs were used basically in the generation of the start models to be inverted.

In order to do 2.5-D inversion of gravity and magnetic data, Webring (1995) elaborated an algorithm based on Marquardt (1963). The algorithm adjusts by least squares the gravity and magnetic theoretical results, according to an adjusted model, to the observed data profile. The model consists of a group of polygons with $n$ sides that map the distribution of densities and susceptibilities in subsurface with a third dimension that forms an angle with the model's polygonal section and extends to an enough distance to avoid border effects. We used this algorithm to improve the 2-D models previously generated.

PROCEDURES Modeling in 2-D and its inversion in 2.5-D followed the procedures: 1 - definition of orthogonal profiles to the geological-structural tendencies approaching to the gravity stations; 2 - determination of the largest number of well-known parameters: density, geology (geologic maps) and the magnetic susceptibility; 3 adjustment of the gravity model anomaly to the field anomaly; 4 inversion of the starting gravity model using the magnetic field profile; 5 - comparison of the magnetic anomaly generated with the observed and proceed to the susceptibility adjustment; 6 - if the susceptibility adjustment result is bad, proceed to the magnetic modeling assuming induced magnetization varying the magnetization direction.

The gravity profiles were extracted from the Bouguer map (Fig. 2) and the magnetic ones were extracted from the data of the Geophysical Project Brazil-Canada. The geologic contacts were based on the geologic map elaborated by Lacerda (1997). Contrasts of densities were based on differences between estimated laboratory (Table 1) values and a mean of $2.667 \mathrm{~g} / \mathrm{cm}^{3}$. Measurements of susceptibilities were kindly supplied by WMC Ltda and were modified as required the model.

3-D automatic inversion According to Cordell \& Henderson (1968), with a given gravity anomaly grid and some restrictions with relations to the mass distribution in subsurface is possible to calculate a three-dimensional structural model automatically by successive approaches. The causative body is assumed to have plane and horizontal top and bottom sections and a given density contrast. The gravity field of that body is calculated to each point of the grid, compared and adjusted to the observed field.

RESULTS AND INTERPRETATION 2-D Models and 2.5D inversion Two profiles were selected in the area of survey. One of them is on the Crixás greenstone belt and the other crosses the greenstone belts of Guarinos and Pilar de Goías.

A 2-D start model was obtained from each profile. The best result was inverted in 2.5-D leaving free the polygon vertexes that didn't 

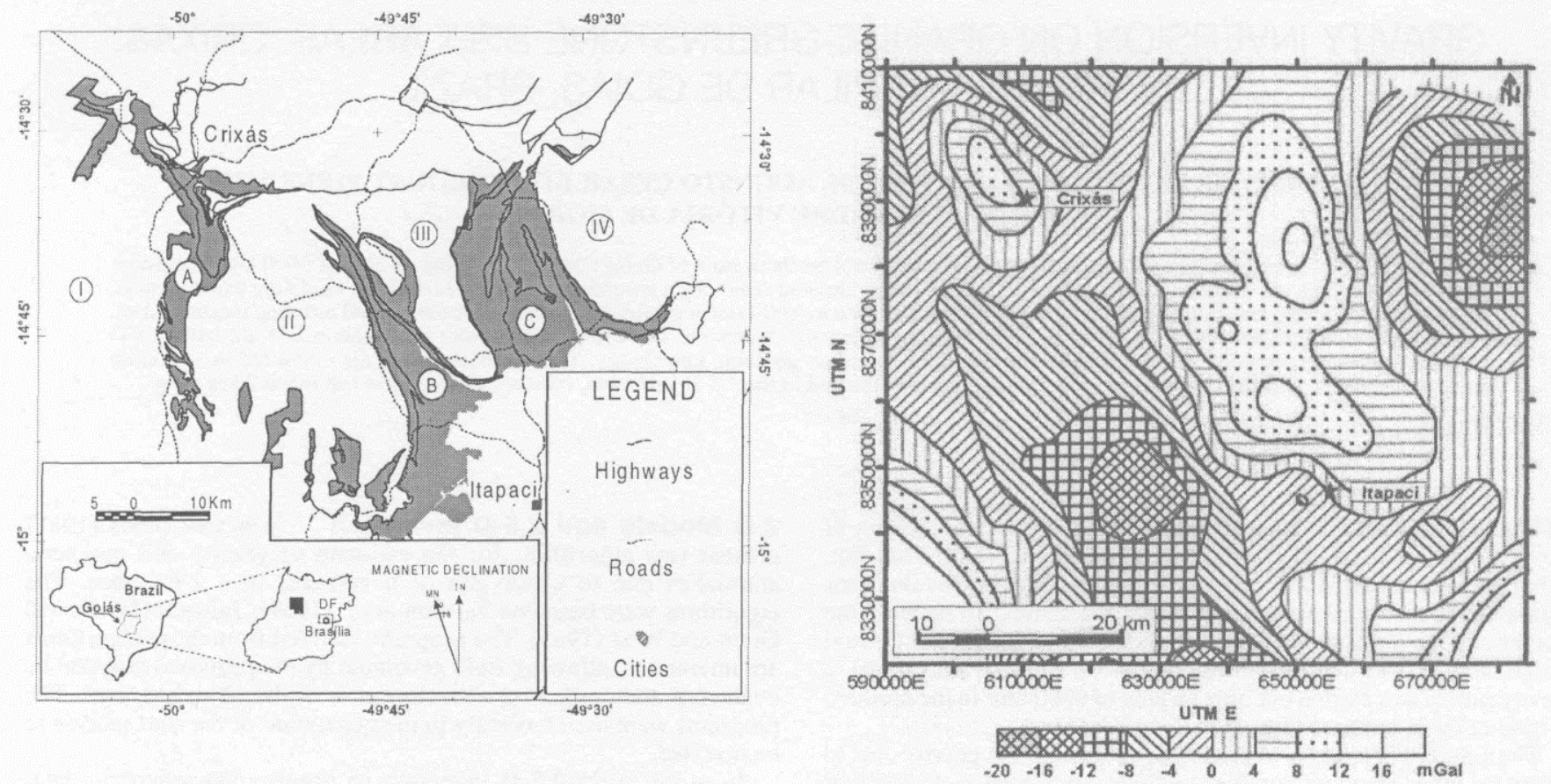

Figure 2 - Bouguer anomaly map without a second-degree trend surface. Contours in $m$ Gal.
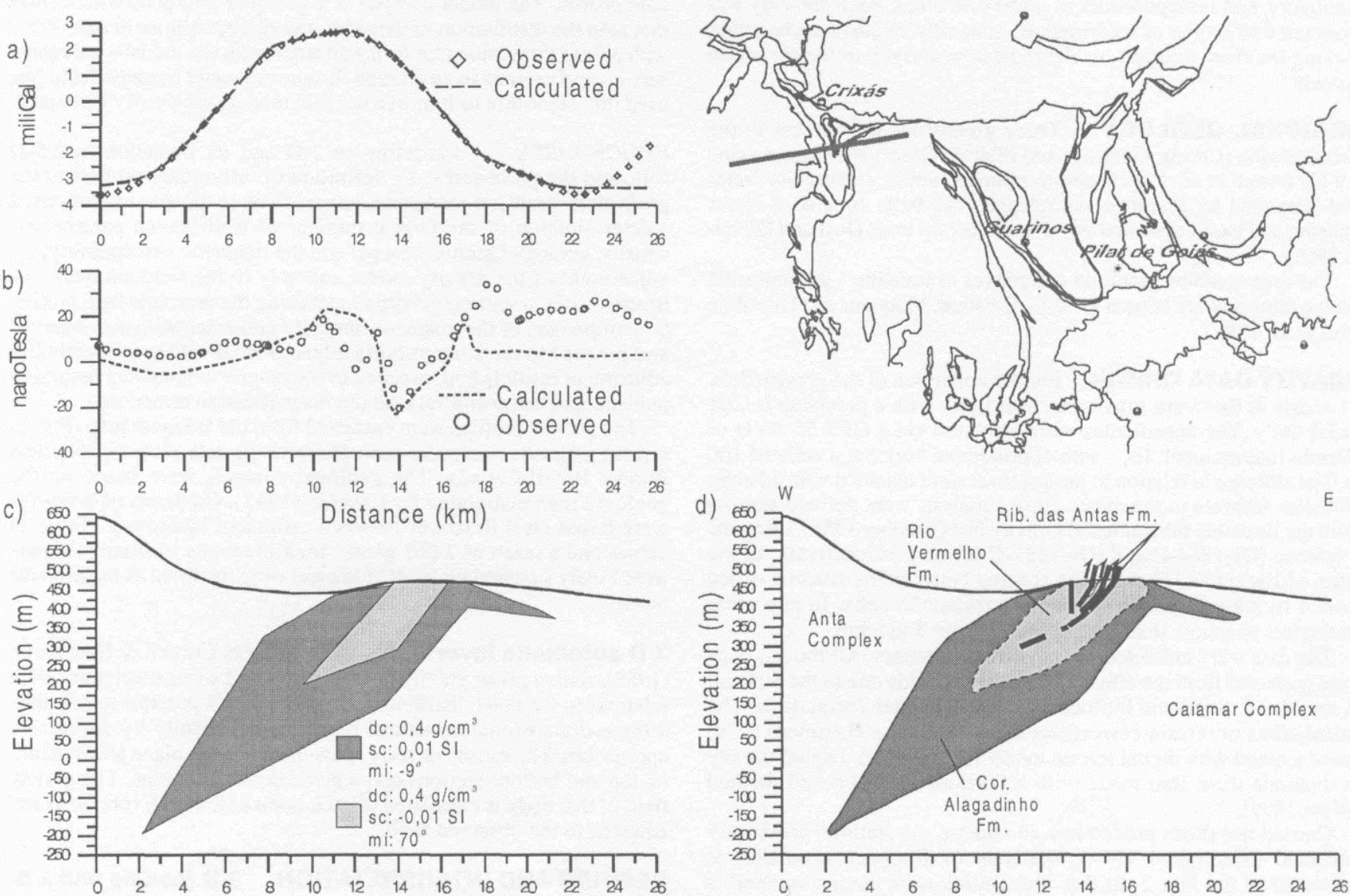

Figure 3 - Profile crossing the central part of Crixás greenstone belt modeled and inverted using gravity (a) and magnetic data (b) by matching the observed and calculated curves, (c) best composite model inverted that satisfies both gravity and magnetic data with respective density and susceptibility contrasts, (d) interpreted geological section based on well-known geology and the best composite inverted model (c). dc- density contrast, sc-susceptibility contrast, mimagnetic inclination. 

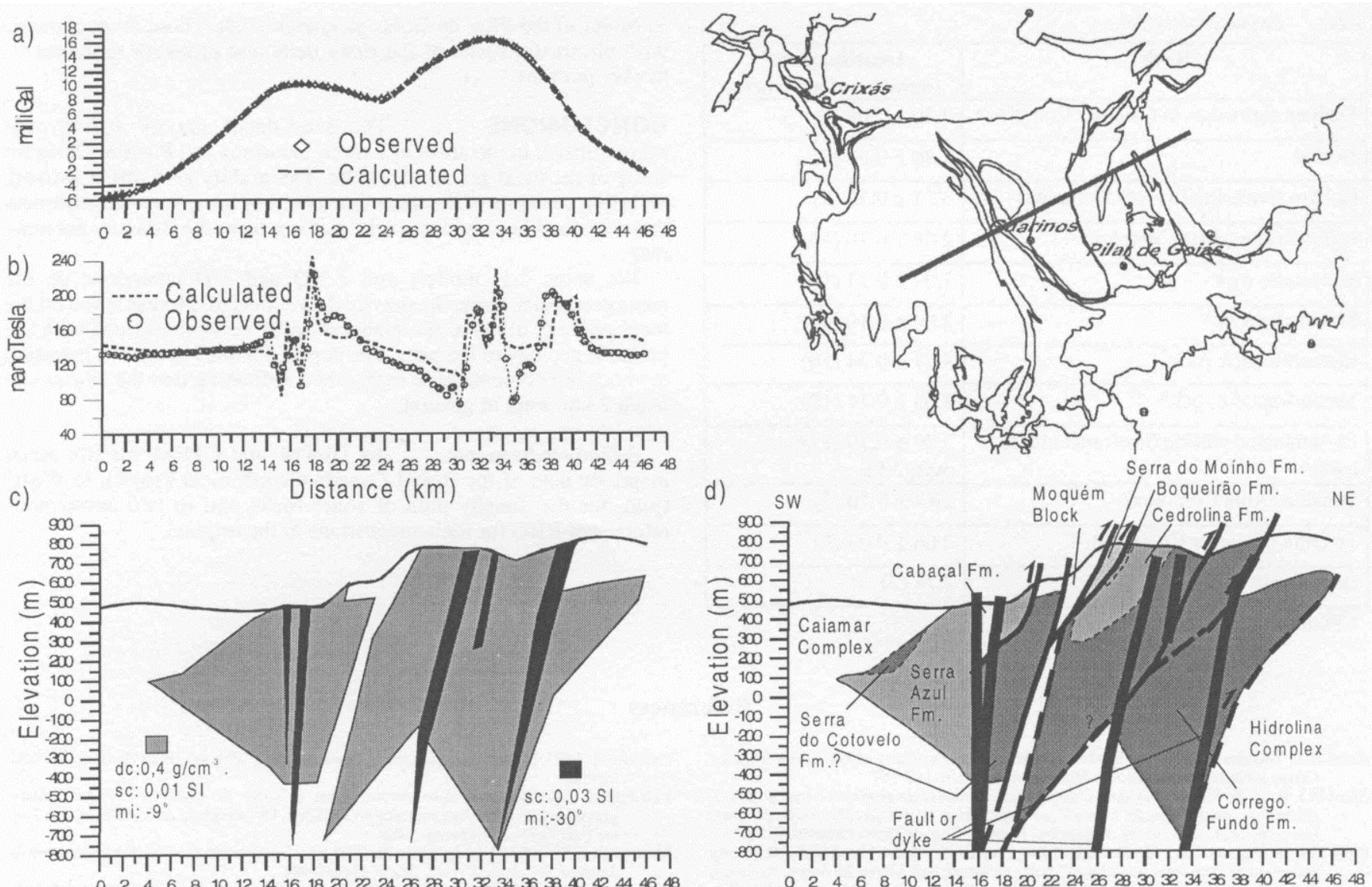

Figure 4 - Profile crossing Guarinos and Pilar de Golds greenstone belts modeled and inverted using gravity (a) and magnetic data (b) by matching the observed and calculated curves, (c) best composite model inverted that satisfies both gravity and magnetic data with respective density and susceptibility contrasts, (d) interpreted geological section based on well-known geology and the best composite inverted model (c). dc-density contrast, sc-susceptibility contrast, mimagnetic inclination.

represent geologic contacts. Figures 3 and 4 show the results of the process and the respective interpretations in the light of the geologic knowledge.

In figure 3, the geologic section (Fig. 3d) were set in Lacerda's map (1997). The insertion of the Ribeirão das Antas Formation and the faults are just pictorial representations. The profile suggests the presence of intrusions that, probably, molded the greenstone belt of Crixás.

The geologic section of the Fig. 4 was based on Resende \& Jost (1995), Jost et al. (1995, 1998), besides Lacerda's map (1997). The format and the positioning of most of the geologic formations and the thrust faults are interpretative based in the geophysical model of the section (Fig. 4c) and in the geologic literature. The presence of flower structures in the Guarinos greenstone belt and in the Moquem Block is also interpretative, even so possible.

The anomalies of the magnetic profiles did not satisfy the gravity models. It occurs probably due to a presence of remanent or viscous magnetization in the greenstone belts. In spite of that, we modeled the main anomalies by variation of the magnetic direction, inclination and susceptibility.

In figure $3 b$, the main magnetic anomaly corresponds to the Rio Vermelho formation (Fig. 3c). Heterogeneity in the main anomaly can correspond to shear zones observed in the geological section (Fig. 3d). In the Fig. 4, the magnetic profile (Fig. 4b) shows that several anomalies coincide with faults of the geologic section (Fig. 4d), reinforcing that the interpreted flower structures are well suggested.

3-D automatic inversion Figure 5 shows the result of the process of automatic 3-D inversion for the whole survey area with top of the body matching the terrain surface. The depths are compatible with the ones that are observed in the inverted profiles (figures 3 and

4). Thickening is observed in three different areas: 1) northwest of the Crixás greenstone belt; 2) south of the Guarinos greenstone belt; and

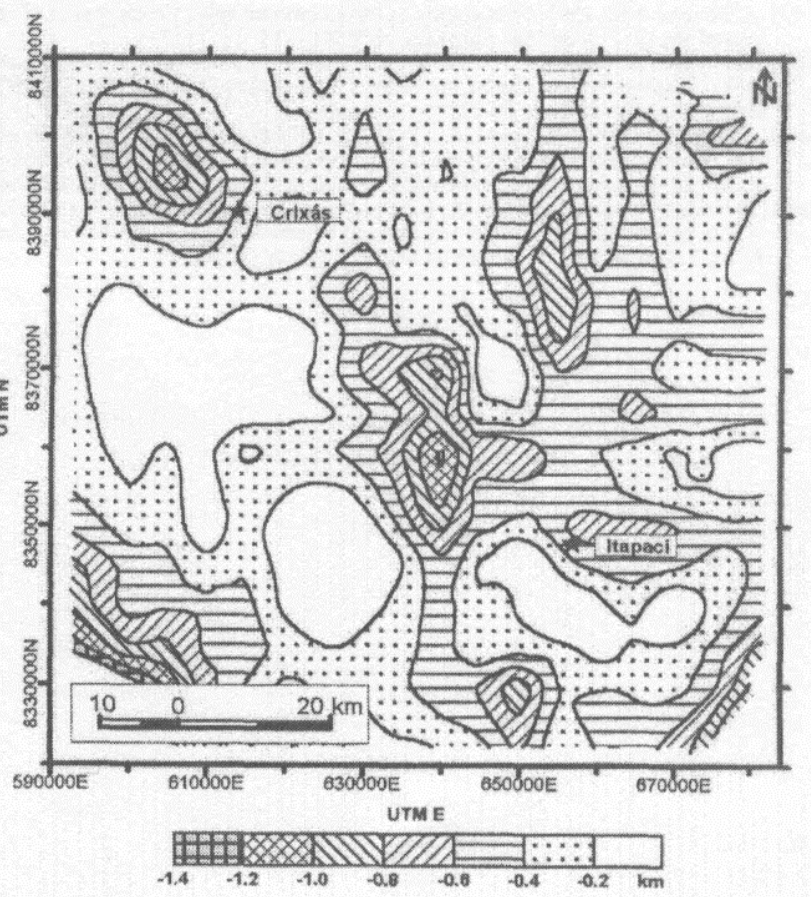

Figure 5 - Automatic 3-D inversion of Bouguer anomaly grid: depths from the terrain level to the source bottom (kilometers). Density contrast: 0.4 $\mathrm{g} / \mathrm{cm}^{3}$. Depths in $\mathrm{km}$. 
Table I - Estimated densities.

\begin{tabular}{|l|l|}
\hline \multicolumn{1}{|c|}{ Rock } & \multicolumn{1}{c|}{$\begin{array}{c}\text { Density, g/cm } \\
\text { (number of measures) }\end{array}$} \\
\hline Diabase (intrusion in Caiamar Complex) & $3.20 \pm 0.08(5)$ \\
\hline Diorite & $2.80 \pm 0.05(3)$ \\
\hline Gabbro (intrusion in Anta Complex) & $3.21 \pm 0.16(5)$ \\
\hline Granodiorite (Anta Complex) & $2.66 \pm 0.20(15)$ \\
\hline Metamafic rock & $3.09 \pm 0.27(13)$ \\
\hline Metamafic rock* & $3.04 \pm 0.16(3)$ \\
\hline Metaultramafic rock & $3.07 \pm 0.34(10)$ \\
\hline Metaultramafic rock* & $3.05 \pm 0.14(19)$ \\
\hline $\begin{array}{l}\text { Disseminated sulfide (host: metamafic } \\
\text { rock)* }\end{array}$ & $\begin{array}{l}3.20 \pm 0.29(11) ; \\
\text { max. 3,95 }\end{array}$ \\
\hline Tonalite (Anta Complex) & $2.67 \pm 0.10(5)$ \\
\hline Tonalite (Caiamar Complex) & $2.66 \pm 0.03(5)$ \\
\hline Quartz vein with sulfide* & $2.74(2)$ \\
\hline
\end{tabular}

* Source: WMC Ltda.

Arndt N.T., Teixeira N.A., White W.M. 1989. Bizarre geochemistry of komatiites from the Crixás greenstone belt, Brazil. Mineral. Petrol. 101:187-197.

Slum M.L.B. 1999. Processamento e interpretação de dados de geofisica aerea no Brasil central e sua aplicação a geologia regional e a prospeccdo mineral. Inst. Geociências, Universidade de Brasilia, Brasilia, Tese de Doutoramento, 229 p.

Blum M.L.B., Pires A.C.B., Mendes L.R. 1996. Preliminary gravity map and 2-D gravity and magnetic data inversion of the Crixás greenstone belt, Goías. In: Symp. Archaean Terrenes South American Platform, Brasilia, 1996. Extended Abstracts... Brasilia, SBG, p.33-35.

Carmo S.D. 1978. Programação e execução do Projeto Geofisico Brasil-Canada. In: Congr. Bras. Geol., 30, Recife, 1978.Anais... Recife, SBG, v.5, p. 2233-2247.

Cordell L. \& Henderson R.G. 1968. Iterative three-dimensional solution of gravity anomaly data using a digital computer. Geophysics 33(4):596-601.

Escobar I.P. 1980. Metodos de levantamentos e ajustamento de observances gravimetricas visando a implantação da Rede Gravimetrica Fundamental Brasileira. Rio de Janeiro, Observatorio Nacional, Publ. No. 1,32p.

Grant F.S. \& West G.F. 1965. Interpretation theory in applied geophysics. McGraw-Hill Book Co.

Hammer S. 1939. Terrain corrections for gravimeter stations. Geophysics, 4:184-194.

Jost H. \& Oliveira A.M. 1991. Stratigraphy of the greenstone belts, Crixás region, Goías, central Brazil. J. South Am. Earth Sci., 4(3):201-214.

Jost H., Carmelo A.C., Meneses, P.R. 1994. Litologias, relações de contato e estrutura do Bloco Caiamar, Crixás, Goías. In: Simp. Geol. Centro-Oeste, 4, Brasilia, 1994. Anais... Brasilia, SBG, p. 18-20.

Jost H., Kuyumjian R.M., Freitas A.L.S., Costa A.L.L., Nascimento C.T.C., Vasconcelos F.M., Gallottti Neto L., Martins M.C.A., Carvalho M.N., Conde V.C. 1995. Geologia da porcao norte do Greenstone Belt de Guarinos, Goías. Rev. Bras. Geoc. 25:51 -60.

Jost H., Resende M.G., Kuyumjiam R.M., Queiroz C.L., Osborne G.A., Blum M.L.B., Pires A.C.B, Moraes R.A.V. 1999. O Arqueano do Estado de Goías. In: Hasui, Y. \& Sena Costa, J.B. (edit.). Geotectonica do Brasil, (in press).
3) center of the Pilar de Goías greenstone belt. Those areas coincide with ultramafic rocks of the three belts and probably represent its thicker portions.

\section{CONCLUSIONS}

The semi-detail gravity survey was accomplished in the areas of Crixás, Guarinos and Pilar de Goías for study of the local greenstone belts. The gravity grid was improved, revealing each one of the three greenstone belts with greater clearness than obtained in previous works starting from the Bouguer anomaly map.

We made 2-D models and 2.5-D and 3-D inversions on the greenstone belts, using the gravity data collected. Models based on the local geology allowed the elaboration of vertical sections with the probable geology of the belts. The depths obtained in the two inversion methods are compatible to each other, indicating that the targets can reach $2 \mathrm{~km}$ deep, in general.

Acknowledgements To DNPM and CPRM for the aerial magnetic data of the Brazil-Canada Geophysical Project, to WMC Ltda, for the density data of some rocks and to two anonymous referees of RBG for their suggestions to the original.

\section{References}

Lacerda H. 1997. Mapa Geologico do "Greenstone Belt" Crixás - Pilar de Goías. CPRM, inedito.

Marangoni Y.R. 1994. Modelo crustal para o None de Goías a partir de dados gravimetricos. Inst. Astronomico e Geofisico, Universidade de São Paulo, Sao Paulo, Tese de Doutoramento, $130 \mathrm{p}$.

Marquardt D.W. 1963. An Algorithm for least-squares estimation of nonlinear parameters Journal Sot: Indust. Appl. Math. 11:431-441.

Parasnis D.S. 1972. Principles of Applied Geophysics. $2^{\text {nd }}$ ed. London. Chapman \& Hall,

Resende L. \& Jost H. 1995. Caractenísticas estratigráficas e petrográficas da seqiiencia metassedimentar do Greenstone Belt de Pilar de Goías. Bol. Geoc. Centro-Oeste,

Talwani M. 1965. Computation with help of a digital computer of magnetic anomalies caused by bodies of arbitrary shape Geophysics, 30(5):797-817.

Talwani M., Worzel J.L, Landisman M. 1959. Rapid gravity computations for twodimensional bodies with application to the Mendocino submarine fracture zone. $J$ Geophys Res 64:49-59.

Webring M. 1985. SAKI: A Fortran program for generalized linear inversion of gravity and magnetic profiles. Open-File Report 85-122, U.S. Geological Survey.

Won I.J. \& Bevis M. 1987. Computing the gravitational and magnetic anomalies due to polygon: algorithms and FORTRAN subroutines. Geophysics 52:232-238.

Contribution IGC-156

Received March 3, 2000

Accepted for publication April 22, 2000 